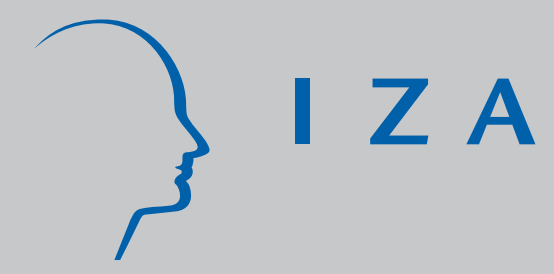

IZA DP No. 3456

The Impact of Population Aging on the Labor Market: The Case of Sri Lanka

Milan Vodopivec

Nisha Arunatilake

April 2008 


\title{
The Impact of Population Aging on the Labor Market: The Case of Sri Lanka
}

\author{
Milan Vodopivec \\ World Bank and IZA
}

Nisha Arunatilake

Institute for Policy Studies, Colombo

\author{
Discussion Paper No. 3456 \\ April 2008
}

\author{
IZA \\ P.O. Box 7240 \\ 53072 Bonn \\ Germany \\ Phone: +49-228-3894-0 \\ Fax: +49-228-3894-180 \\ E-mail: iza@iza.org
}

\begin{abstract}
Any opinions expressed here are those of the author(s) and not those of IZA. Research published in this series may include views on policy, but the institute itself takes no institutional policy positions.

The Institute for the Study of Labor (IZA) in Bonn is a local and virtual international research center and a place of communication between science, politics and business. IZA is an independent nonprofit organization supported by Deutsche Post World Net. The center is associated with the University of Bonn and offers a stimulating research environment through its international network, workshops and conferences, data service, project support, research visits and doctoral program. IZA engages in (i) original and internationally competitive research in all fields of labor economics, (ii) development of policy concepts, and (iii) dissemination of research results and concepts to the interested public.
\end{abstract}

IZA Discussion Papers often represent preliminary work and are circulated to encourage discussion. Citation of such a paper should account for its provisional character. A revised version may be available directly from the author. 
IZA Discussion Paper No. 3456

April 2008

\section{ABSTRACT \\ The Impact of Population Aging on the Labor Market: The Case of Sri Lanka*}

Sri Lanka's population is predicted to age very fast during the next 50 years, bringing a slowdown of labor force growth and after 2030 its contraction. Based on an original, 2006 representative survey of old people in Sri Lanka conducted as a part of this study, the paper examines labor market consequences of this process, focusing on retirement pathways and the determinants of labor market withdrawal. The paper finds that a vast majority of Sri Lankan old workers are engaged in the informal sector, work long hours, and are paid less than younger workers. Moreover, as one of the first findings of its kind, the paper shows that labor market duality that characterizes most developing countries carries over to old age: (i) previous employment is the most important predictor of the retirement pathway; (ii) older workers fall into two categories: civil servants and formal private sector workers, who generally stop working before they reach 60 because they are forced to do so by mandatory retirement regulations, and casual workers and the self-employed, who are forced to work until very old age (or death) due to poverty and who stop working primarily because of poor health; and (iii) the option of part-time work is used primarily by workers who held regular jobs in their prime age employment, but not by casual workers and self-employed.

JEL Classification: $\quad \mathrm{J} 11, \mathrm{~J} 14, \mathrm{~J} 26$

Keywords: $\quad$ population aging, labor supply of old workers, labor demand for old workers

Corresponding author:

Milan Vodopivec

The World Bank

1818 H Street, NW

Washington, D.C. 20433

USA

Email: Mvodopivec@worldbank.org

\footnotetext{
* The authors would like to Gordon Betcherman, Ralitza Dimova, Ravi Peiris, Ravi Rannan-Eliya, Shyamali Ranaraja, Mansoora Rashid, and Nimnath Withanachchi for useful comments, and Priyanka Jayawardena for excellent research assistance. Partial funding under the TFESSD trust fund grant is gratefully acknowledged.
} 


\section{INTRODUCTION}

In slightly more than two decades, Sri Lanka’s population will be as old as Europe’s or Japan’s today, but its per capita income will be much lower. Indeed, while population aging is a universal phenomenon, it looms particularly large for Sri Lanka: not only is its population among the oldest in the non-developed world, but Sri Lanka is also one of the fastest aging countries in the world (Figure 1). Spectacular growth would be required for Sri Lanka to catch up the developed countries' current aging profile at a level of per capita income these countries currently enjoy.

In developed countries, challenges of population aging are associated primarily with the negative impact of aging on economic growth, and the need to plan for additional public and private outlays for old age income support and healthcare (MacKellar 2000). In Sri Lanka, a developing country, these challenges are compounded by several facts. First, in 2006 only a tenth of the old people received pensions as their major source of income and a third non-pension government assistance, so most of them rely on family support as key for their wellbeing. With only one third of the labor force presently covered by social security programs (World Bank 2007a), the need for the family support is likely to remain high in the next decades. Second, rapid aging and modernization may put a strain on the traditional family support to old people. The modernization of Asian societies is associated by several mechanisms that affect family support of old people (Hermalin 2002) - lower fertility translating into fewer children available to provide familial support; higher education levels leading to differences in attitudes and perceptions of obligations to provide familial support; increased female labor force participation reducing the number of caregivers available to provide support to older family members; and rural-urban migration drawing younger persons out of rural areas to find employment. ${ }^{1}$ Third, the health system is insufficiently focused on the healthcare needs of elderly and is constrained by the lack of resources and their inequitable distribution (World Bank 2007b). And fourth, population aging may well translate into shrinking of the labor force, prompting questions of how to promote longer working lives - and also of how to improve labor market choices for those that are forced to continue working late in their lives.

This paper focuses on the last challenge - the impact of population aging on the labor market. The analysis focuses on the current labor market outcomes of old workers and attempts 
to identify both the work incentives of old people and the constraints faced by them (such as poor health and lack of employment opportunities). ${ }^{2}$ The paper finds that a vast majority of Sri Lankan old workers are engaged in the informal sector, work long hours, and are paid less than younger workers. Moreover, as one of the first findings of its kind, the paper shows that duality that characterizes labor markets of most developing countries carries over to old age: (i) previous employment is the most important predictor of the retirement pathway; (ii) older workers fall into two categories: civil servants and formal private sector workers, who generally stop working before they reach 60 because they are forced to do so by mandatory retirement regulations, and casual workers and the self-employed, who are forced to work until very old age (or death) due to poverty and who stop working primarily because of poor health; and (iii) the option of parttime work is used primarily by workers who held regular jobs in their prime age employment, but not by casual workers and self-employed.

The paper is organized as follows. To set the stage, Section 2 presents long term labor force projections and discusses economic implications of the slowdown of labor force growth and its shrinking. The next sections analyze labor market outcomes of old workers: Section 3 describes key employment and pay outcomes for old workers and the patterns of their withdrawal from working life; Section 4 examines pathways to retirement, that is, typical ways in which workers transit from full-time employment to complete retirement; and Section 5 explores the determinants of work activity of old workers with multinomial logit models. Section 6 discusses possible obstacles for employment in old age, and Section 7 concludes with policy implications.

\section{LABOR SUPPLY AND GROWTH IMPLICATIONS OF POPULATION AGING}

Sri Lanka's population is set to age rapidly during the next 50 years, with the proportion of old people increasing substantially. The main drivers of this process are low and declining fertility and increasing life expectancy. The total fertility rate (the number of children that the average woman bears during her lifetime) fell below the replacement level of 2.1 by 1994 and it has continued to fall, reaching 1.7-1.9 in the 2000s. Increasing life expectancy is another driver of Sri Lanka's population aging. Currently life expectancy for men is 69 years and for women is 77 years, higher than in most developing countries, and present trends indicate that life expectancy 
will reach the current average OECD level of 77.8 years by 2050 (OECD, 2005). Central to Sri Lanka's demographic aging will therefore be an increase in the share of the old people, with the share of peopled aged 60 years and above projected to increase from current 11 percent to 16 percent in 2020 and to 29 percent in 2050 (Figure 1). According to De Silva (2007), the share of very old people (80 years and more) will also strongly increase. Because in the next 2-3 decades the increasing old age dependency ratio (the proportion of population aged 60 years or more versus the proportion aged 15-59 years) will be roughly matched by the fall in the child dependency ratio (proportion of population aged less than 15 years versus the proportion aged 15-59 years), the overall dependency ratio is projected to start increasing rapidly after 2035 (Figure 2).

Population aging will translate into a slowdown of labor force growth and later into its contraction, and its composition will also be affected. Labor force projections show that Sri Lankan labor force will continue to grow for another two decades, and it will shrink thereafter in a foreseeable future. ${ }^{3}$ Applying constant current labor force participation rates to population projections, Figure 3 shows that labor force will stop growing around 2030 (in 2027, 2032, and 2037 for the low, standard, and high population scenario, respectively), and will thereafter start to shrink, dropping to the current size of the labor force in about 30 years under the standard population scenario. ${ }^{4}$ Population aging will also significantly change the age composition of the labor force, with the share of workers younger than 30 years significantly shrinking and the share of those older than 50 years strongly increasing (Figure 4).

With labor force growth being one of the sources of economic growth, the slowdown of labor force growth and its shrinking after 2030 may contribute to a slowdown in GDP growth. While simulations that would determine the aging-induced "tax" on GDP growth is beyond the scope of this paper, it is instructive to present some estimates of this tax for other countries. Because of population aging, the forecast of GDP per capita growth in the OECD area is reduced to around 1.7 percent per year over the next three decades, bringing about 30 percent reduction in comparison to the 1970-2000 growth rate (OECD 2006). Martins et al (2005) estimate that in the next half century, the decline of their workforces will contribute to a reduction of the per annum growth rates by 0.2 to 0.5 percentage points in France and Germany, and by 0.8 percentage points in Japan. Moreover, because of the raising share of inactive population, the economic growth in Japan, France and Germany will slow down by additional 0.2 to 0.3 percentage points, 
compared to growth under a stable age structure of the population. For comparison, about one quarter of the growth of OECD countries in recent decades has been attributed to labor force growth (Martins et al 2005).

Population aging, however, may not necessarily reduce economic growth, if countervailing factors prevail. A drag on economic growth created by population aging could be countered by higher overall (multifactor) productivity, increases of labor quality, or increased labor force participation. While it is hard to predict the changes of multifactor productivity, recent trends show that education level of workforce has improved significantly in the recent 15 years (the share of workers with finished A level or above has increased by 5 percentage points, and with commensurate reduction of workers with less than 5 years of schooling), and the quality of workforce is likely to improve further in the future. Another plausible countervailing factor is the increase of labor force participation rates - for example, simulations show that the increase of women's participation rate by 20 percent could delay the reduction of labor force by 15 years. ${ }^{5}$

\section{WORKING IN OLD AGE}

Below we describe key labor market outcomes for old workers, focusing on the timing of retirement, work load, manner of retirement (how quickly people transit from full-time employment to complete retirement and the use of part-time work before reaching complete retirement), changes in the sector of work and occupation, and reasons for retirement.

\section{Labor force participation and unemployment of old people}

During 1992-2004, labor force participation of old workers remained stable, men's participation rate by far exceeded women's, and the withdrawal from a labor market occurred rather late in the life cycle (Figure 5). The only exception in regard with stable trends was a rising LFP rate of females aged 50-59, increasing from 26 percent in 1992 to 33 in 2004; in contrast, LFP for males in that age show no pronounced trend and remained in the 51-56 percent range (Figure 6). Workers were withdrawing from the labor market rather late in the working career - starting with the age group 60-69, for males, and with the 50-59, for females (Table 1). For males, LFP rates for all age groups in the prime age (20-59) exceeded 80 percent, dropping to the 50s in the age group 60-69 and to around 20 percent in the age group over 70. Withdrawal for the women 
starts somewhat earlier - in 2004, LFP rates in the age group 40-49 were about 44 percent, dropping to 33 percent in the age group 50-59, to 14 percent in the age group $60-69$, and to 3 percent in the age group over 70 .

Unemployment among old Sri Lankans is a rather uncommon phenomenon. During 1992-2004, unemployment rates for males aged 60-69 were typically well below 1 percent and virtually 0 for those over 70 years; unemployment rates for old women were even lower (Table 2). These figures reflect both the fact that when losing their jobs, old workers tend to withdraw altogether from the labor market (the phenomenon called "hidden unemployment" by OECD 2006). Unemployment rates are rapidly falling with age for both men and women (Figure 7). In 2004, 15-19 year olds had the highest unemployment rates, amounting to 26 and 37 percent, respectively, for men and women, with unemployment rates for older age groups monotonically decreasing and reaching single digit numbers already in the age group of 30-39 year olds.

More rigorous analysis confirms strong association of labor force participation and unemployment with age. The above associations were obtained from cross-sectional data and not from observing the same set of individuals through time, and changes in the composition of persons observed in different age categories may influence the results. Accounting for such differences, probit regressions, run separately for males and females, confirm that age has a strong influence on the labor force participation and unemployment of individuals. ${ }^{6}$ Relative to labor force participation of individuals aged 20-24, the marginal effect of age is very strong in the late 20s, remaining flat till about the late 40s, and becoming increasingly negative for both males and females (not shown). Similar probit regressions also confirm the association of age with unemployment rates, with age accounting for a much larger reduction of unemployment rate between early 20s and late 30s for women than for men.

International comparisons show that Sri Lanka's labor force participation rates for old people lag behind the rates of its regional comparators while mostly exceeding those in developed countries. Labor force participation of older men is lower than in other countries in the region (India, Thailand, Bangladesh and Pakistan, Table 3), and so is participation of women, except that women's participation rate in Sri Lanka exceeds the one in predominantly Muslim countries (Pakistan and Bangladesh). Interestingly, the LFPs of elderly in Sri Lanka also lag behind the rates of Japan, but they exceed other developed countries. 
Unemployment rates of elderly Sri Lankans are in line with those of regional comparators and lag substantially behind developed countries. Unemployment rates for elderly - both males and females - in Sri Lanka are similar to those in India and Thailand, where open unemployment among old workers is also virtually unknown. Reflecting a different institutional set-up - above all, the existence of specialized programs providing cash benefits to unemployed that stimulate labor force attachment - unemployment rates of old workers in developed countries are significantly higher than in developing countries (although they are still much lower than youth unemployment rates in these countries). In 2004, unemployment rates for workers aged 50-64 ranged from 2 percent in Norway to 11 percent in Germany (OECD 2006).

\section{Employment status, work load and pay of old workers}

Most of the old workers have full-time rather than part-time jobs. As shown above, as they age, fewer and fewer workers remain employed. But if they do, they tend to work in full-time jobs rather than part time. In our survey of old people, 30 percent of males were employed, of whom two thirds were in full time employment and only a third in part-time employment; only 5 percent of women were employed, with 60 percent of them in full-time employment. The proportion of part-time employment among old workers was the lowest in the 60-64 age group and then increased for older groups of workers, with the share of part time workers exceeding the share of full-time workers in the 75-79 age group (see Figure 8). ${ }^{7}$

The most prevalent way of withdrawing from the labor market is "overnight," that is, without engaging in part-time employment. As implied by falling LFPs and the fact that parttime work is relatively infrequent, most workers exit from full-time employment directly to complete retirement. In our sample of individuals who held stable jobs in their early fifties (see selection details below), a vast majority (89 percent) of workers who did not work full time any longer had retired "overnight," that is, they did not work part time before retirement and they completed transition to inactivity in a very short time.

The number of hours worked is also reduced by age. Reflecting retirement patterns, old workers as a group are providing less and less labor to the economy. The average weekly number of hours of work provided by old male workers decreased from 23 for 60-63 year olds to below 10 for the 72-75 year olds; and by old female workers, from 5 and 2 for the same are groups (Figure 9a). At the same time, workers staying active reduce the number of hours worked as they 
age, men from the average of 47 in their early sixties to 36 in the 72-75 year group, and women from 35 to 29 for the same age groups (Figure 9b). Despite these reductions, the average numbers of work for those workers who remain employed remain large even in high age. Old workers in part time jobs also work long hours - in our sample (SLAS 2006), they on average work only 12 hours less than old workers in full-time jobs (36 hours compared to 48).

In comparison to younger workers, old worker are paid less, particularly in the public sector. Wages of workers of 65 years and above are only a fraction of wages of the best paid group of workers - workers in their late 50s and early 60s, in the public sector, and in their 30s, in the private sector (Figure 10). Particularly strong reduction of wages of older workers occurs in the public sector, with workers aged 65 and over earning barely over 1/3 of what the workers in the 60-65 group are earning, and only about 20 percent of what workers in the 55-59 year group are earning (the latter applies for women only). In the private sector, the reduction of wages for workers above 65 years of age is more modest. Interestingly, except for women in the public sector, wages of workers in the 60-64 year group are higher than wages of the 55-59 year group. ${ }^{8}$ One salient feature of the age-wage profiles is the fact that the both men's and women's profiles of the private sector are much flatter than the ones in the public sector. Many OECD countries have hump-shaped age wage profiles, but there are many exceptions, reflecting different institutional wage-setting and other arrangements (see OECD 2006).

\section{Where and as what do elderly work?}

A vast majority of old workers are self-employed or casual workers engaged in the informal sector. More than half of the working elderly males and females are self-employed (Figure 11a). Majority of the rest of workers are casual workers, with less than 3 percent of elderly working as regular workers, mostly workers in their early sixties. Vast majority of old workers are engaged in informal private sector (the main exception being men in their early sixties, with small share of them working for the government or in the formal private sector) - see Figure 11b.

Old workers, both males and females, are working mostly as skilled workers in agriculture, manufacturing, and wholesale and retail trade (Figure 12). A fair proportion of them, particularly of women, are working also at the bottom of occupational ladder (in elementary occupations), and a small proportion as professional workers. Not surprisingly, the composition of workers by occupation changes little with age, as does sector of work, except that the share of 
workers in agriculture is reduced. While sector of work and status for old workers working parttime does not differ much from full-time workers, a larger share of them are professional and skilled workers.

\section{Reasons for retirement and part-time work}

The main reasons for retirement are on the push side: ill-health and reaching mandatory retirement age, for both males and females. ${ }^{9}$ Nearly half of retired old workers stated that health reasons were very important for their decision to retire, and about 40 percent of them quoted reaching the mandatory retirement as being the second most important reason (Table 4). Among the push factors, work and travel stress, as well as the closure of businesses were also important factors affecting the decision to retire.

Among the pull factors, "doing other things (hobbies)" was an important reason for retirement, especially for females (Table 4). Only females found family obligations a very important reason for complete retirement; however, it was a relevant factor only for a small proportion of females. This indicates that obligations of child-care and care for old persons do not have a large effect on retirement decisions.

Earning additional income was the main reason for part-time employment for most workers. Three in four elderly in part-time employment are continuing to work to earn additional income. More females than males consider the additional income from part-time employment as the main reason for continued employment. A small percent also worked part time to keep them selves occupied (6 percent) and to be in touch with their profession (3 percent). A large share of elderly working part-time does so involuntarily, as 80 percent of those who retired after doing some part-time work indicated that they would have liked to stop work completely after retirement from full-time work. (On the other hand, over a quarter of the surveyed old people indicated that they would have liked to continue doing some paid work when they retired from their full time jobs.)

The reasons for retirement differ substantially from those in OECD countries. Similar to workers in OECD countries, a share of workers retires upon reaching mandatory retirement age. However, unlike in OECD countries, the single most important reason for withdrawal from the labor market is poor health. A smaller share of workers is also pulled into retirement by family obligations, work stress, travel stress and work dislike. Moreover, in OECD countries there are 
many institutional arrangements that entice old workers to retirement or early retirement, ranging from pre-retirement pension schemes to disability and unemployment insurance benefits (OECD 2006) - the arrangements largely missing in Sri Lanka.

\section{PATHWAYS TO RETIREMENT}

Above we analyzed the patterns of withdrawal from working life as people age, treating the population of old people as a whole. Remembering a key motivation for this investigation identifying ways to promote choice for old workers in both improving job prospects as well as reducing pressures on those who are forced to work - it is helpful to find out whether the working careers themselves determine the fate of workers in their old age. Recognizing the deep segmentation of the Sri Lankan labor market, we do so by tracing retirement paths - typical sequences of labor market arrangements between full-time work late in the working career and a complete retirement/withdrawal from active working life - for different groups along these segmentation lines. We therefore focus on the following four groups of workers: ${ }^{10}$

- Regular public sector workers (i.e., regular workers of public sector, public corporations or boards and the co-operative sector),

- Regular private sector workers (i.e., regular workers of both the formal and the informal private sector),

- Casual workers (i.e., casual and contractual workers), and

- $\quad$ Self-employed (i.e., employers and the self-employed).

In our analysis of retirement pathways and exploiting the data from the SLAS 2006, we focus on the following aspects (the most relevant ones among the aspects studied in the previous subsection): timing of retirement, manner of retirement (“overnight” vs. via part-time employment), changes of sectors of work and occupation, and reasons for retirement. Note that for this analysis we exploited a panel nature of the SLAS 2006 - the fact that in addition to being asked asking about their current employment status, respondents were retrospectively asked also about the age of retirement from their full- and part-time job, as well as their employment status when whey were in their early fifties, that is, at the end of their prime-time work career. Based on this information, we selected 1060 workers with stable jobs in their early fifties (they held 
full-time jobs and were continuously working when they were 51-54 years old), and traced their work history continuously into their old age. ${ }^{11}$

Our results confirm that pathways to retirement show strong dual patterns. The majority of regular workers in public and private sector retire early, most of them before they reach 60 , and for work-related reasons (including mandatory retirement); in contrast, a large share of selfemployed and casual workers continues to work full-time into very old ages, and most of them withdraw from employment for health reasons. The option of part-time work is also used primarily by workers who held regular jobs in their prime age employment, but not by casual workers and self-employed. The results show that labor market duality, the hallmark of labor market in many developing countries, carries over to old age and importantly determines the fate of old people. We present detailed results below.

Timing of retirement: regular public and private sector workers withdraw from the labor market much earlier than casual and self-employed workers. More than two thirds of workers holding regular jobs in the public sector in their prime age, and 57 percent of workers holding jobs in the private sector, completely retired when they were 60 years old. In contrast, only 23 and 18 percent of workers who were casual workers or self-employed in their prime age retired when they reached the age of 60 , with the gap in retirement status widening with the age of workers (Figure 13)! When they reach 69, virtually none of the workers who have spent their careers in the formal sector is still working full time; in contrast, nearly half (47 percent) of their counterparts who were casual workers and self-employed are still working full time. ${ }^{12}$ Note that in terms of occupations, the first two categories comprise mostly of white-collar workers (officials, managers, clerks and professional), in contrast to predominantly blue-collar workers comprising the casual and self-employed (who were mostly skilled agriculture and fishery workers, craft and related workers, and workers in elementary occupations). The observed pattern of retirement is thus contrary to the one found for OECD countries, where blue-collar workers and less-skilled workers are more likely to retire earlier (see OECD, 2006).

Another way of looking at differences at retirement patterns is to observe retirement ages. Figure 14 shows retirement from full-time employment for the selected sample of individuals who held stable jobs in their early fifties described above. The distribution of retirement age is similar for regular public and private sector workers, with the 95 percent of workers from the first group and 84 percent from the second group retiring between ages 55 and 64 (for public 
sector workers, there are clear peaks at ages 55 and 60, due to mandatory retirement - not shown on the graph). In contrast, the distribution of retirement age for informal sector workers spreads in much higher age, with 16 and 18 percent of casual and self-employed workers, respectively, retiring when aged 76-80.

Manner of retirement: the majority of workers across all groups retire overnight, with labor market withdrawal via part-time employment being more common for regular workers. In our sample of individuals who held stable jobs in their early fifties, 11 to 13 percent of regular public or private sector workers held part-time jobs by the time of the survey, and only 6 percent of casual and self-employed workers did. (Note that at the time of the survey, around 40 percent of casual and self-employed still held full time jobs and very few among the regular workers.)

Industry and occupational composition: changes occur primarily for regular but not for casual and self-employed workers. Proportions of elderly in different industrial sectors remain constant for casual and self-employed workers (see Figure 15). In contrast, among workers who held regular jobs at the end of their prime-age working career, a proportion in agriculture increases with age (after age of 67, workers with jobs in public sector tend to withdraw from the agriculture and their share in industrial sector increases). Similarly, occupational composition for casual and self-employed workers shows little change with time, while among workers who held regular jobs at the end of their prime-age working career, the share of skilled workers increases and the share of professional workers decreases with age (not shown).

Reasons for retirement: most workers are pushed away from jobs, but while for regular public and private sector workers the main reason is mandatory retirement age, for casual and self-employed workers is ill-health. For regular public sector workers, the main reason for retirement at any age is work related, primarily reaching mandatory retirement age (see Figure 16). The same holds true for regular private sector workers, except for those aged 61-70. Overall, a slightly over a quarter of regular workers in the private sector cited reaching mandatory retirement age as a reason for retirement from full time work. On the other hand, by far the most compelling reason for retirement at all ages for casual workers and self employed was ill health (a small exception are casual workers aged 55-59, where work-related reasons slightly overweigh health reasons). Interestingly, personal reasons figured more prominently for the groups of casual workers and self employed than for regular workers. 


\section{DETERMINANTS OF RETIREMENT}

The above analysis is mainly descriptive, examining the retirement from active working life through a "single lens," that is, one aspect at the time (section 3), and contrasting retirement patterns across workers with different employment status during their working life (section 4). In this section, we extend the approach to multivariate analysis, that is, to the identification of the separate influence of individual variables on retirement decisions, the influence that may be clouded in a simple, univariate analysis.

Speaking formally, below we report the results of multinomial logit models identifying factors that contribute to the withdrawal from the labor market. The dependent variable is the change of the labor market status of individuals holding stable, full-time jobs at age 54 years old as compared to their status when they were 61-65 year old (1060 persons in the SLAS). According to work status during ages 61 to 65, we allow three possibilities for this change (that is, our dependent variable can take three values):

- Completely retiring upon reaching 61 years and not working when aged 61-65 (in our sample, 382 individuals); this transition was taken as a baseline.

- Working at least some time during ages 61-65, either part time, or full-time if not throughout the period (in our sample, 208 observations).

- Working continuously full-time during ages 61-65 (in our sample, 470 observations).

Among explanatory variables, labor market factors, as well as family, demographic and personal characteristics are included (see Table 5 for descriptive statistics of independent variables). Of the sources of income considered in the study, inclusion of financial or in-kind family assistance could be endogenous, if one believes that the amount of help given by family vary according to other sources of income, and health status of elderly. Hence, instead of using family assistance, we use a proxy variable, which indicates whether individuals have access to help if they need it. Statistically significant results of this analysis are highlighted below.

Employment status at age 55 is the most important factor determining work activity of old workers. The results show that keeping other things constant, compared to regular public sector workers, all other types of workers are more likely to be working full-time during ages 61-65 (Table 6). These effects are large for workers of all three groups - regular private sector 
workers, and particularly for casual and self-employed workers: workers from the first group are 40 percent more likely to work in a full-time job in their early 60s than workers who left regular public sector jobs, and casual and self-employed workers 66 and 69 percent more likely, respectively. Interestingly, while casual and self-employed workers are more likely to work full time, but they are less likely to work part time as compared to workers who were regular public sector workers at the end of their working career. In other words, while the option of working part time is open to previous regular public sector workers, this option seems to be less available to casual and self-employed workers.

The probability of working in old age decreases progressively with (self-perceived) health problems and the presence of chronic illnesses. The results show that relative to individuals who reported very good health, the probability of full-time or part-time work of individuals who reported good or poor health is significantly smaller - for those in poor health, the chances for full-time work are 23 percent smaller, and for part time work 4 percent smaller, in comparison to those in very good health. Similarly, the probability of full-time (but not parttime) work of individuals who reported a chronic illness is also significantly smaller (by 11 percent) in comparison to individuals who did not report a chronic illness.

Pension income is a major factor reducing labor supply of elderly. The results of the multinomial model show that pension income has a large and negative effect on work activity in old age. Receiving a pension reduces the probability of full-time work by 21 percent and that of part-time work by 7 percent. Location also affects elderly work activity, but the effects are small. Estate sector workers are less likely to work full-time during ages 61-65, relative to urban sector workers. This could possibly be due to the high level of strenuous physical activity associated with estate sector work.

Interestingly, individual characteristics - gender, ethnicity, marital status, being a head of a household - have no significant effect of the studied labor market transitions. We do find, however, that men are more likely then women to make a transition to part-time jobs, as do previously married workers as compared to currently married. 


\section{OBSTACLES FOR EMPLOYMENT OF OLD WORKERS}

A wide range of outcomes in the Sri Lankan labor market is suggestive of a presence of rigidities regarding employment conditions faced by old workers. We showed that old workers long relatively long working hours - according to the 2006 SLAS, only 12 percent of old workers in part-time employment and 8 percent in full time employment were able to adjust their working hours. Moreover, only 8 percent of retired workers had the option of reducing the number of working hours in their last full-time job, and about a quarter of the old workers who retired overnight would have preferred to do some paid work before completely retiring. Other findings of the analysis above complement this picture: we showed that the main reason for retirement of many regular workers was mandatory retirement, that only a small part of workers take part-time employment jobs, and that LFP rates of old workers in Sri Lanka are lower than in regional comparators. Below we probe into the possible obstacles for employment of old workers inflexible employment legislation, high relative wages of old workers, and work stress and weak employability of old workers.

\section{Inflexible employment legislation}

While lack of adjustment of working hours, low LFP rates, and the fact that people are retiring despite wishing to continue working in paid jobs are suggestive of inflexibilities, there may be other reasons for apparent rigidities in the labor market outcomes of old workers. Employers may be reluctant to hire old workers on part-time basis because doing so provokes difficulties of coordinating work in teams; it may generate demands of other groups of workers to offer reduced working hours to them as well; and, possibly, runs against outdated attitudes of employers about part-time employment. Note that the obligation to pay gratuity does not work against old workers, because their relative pay is low (see the discussion of age wage profiles above).

Sri Lanka's strict employment protection legislation, embodied in the 1971 TEWA system, however, may be a source of disincentives for employment of old workers. ${ }^{13}$ In principle, it is not possible to predict the impact of strict employment protection legislation (EPL) on labor market outcomes for old workers, as it may lead to both greater retention of old workers as well as to the reduction in their hiring. While the empirical evidence is weak, some recent studies report negative effects of strict EPL on employment of old workers. For example, 
a cross-section analysis of OECD countries shows a statistically significant association of strict EPL with reduction of employment and hiring rate of workers aged 50-64 (OECD 2006). There is also a number of country studies which identified strict EPL as a barrier to the hiring or retention of older workers.

There is another channel through strict employment protection legislation affects employment of old workers - it encourages the use of mandatory retirement stipulations in employment contracts. While in Sri Lanka there is no legally binding retirement age (except for civil servants), employment contracts typically do specify the retirement date. The reason is simple: similar to other countries with large separation costs, setting the retirement data avoids costly layoffs. ${ }^{14}$ Because Sri Lankan employers can extend employment contracts of old workers beyond pre-set retirement dates, or hire old workers who retired from other firms, without being liable to severance payments (except gratuity), the necessary flexibility in employing old workers is achieved. Increasing the mandatory retirement age for civil servants, set currently at 55, would probably help keeping these workers employed for a longer time, but there is a host of other consideration that should be taken into account (above all, setting consistent hiring practices and considering revisions of wage scales) for this measure to be useful rather than just to increase the costs of bureaucracy.

\section{Are wages of old workers set too high?}

Setting the level of wages too high could work against the employment of old workers. More precisely, if wage increases associated with age exceed the increases in worker productivity, employers would prefer hiring young workers and would be reluctant to retain old workers. ${ }^{15}$ Indeed, in many countries wages by age show a hump-shaped profile, the profile that is most consistent with high level of employability of old workers (see OECD 2006 for a description of such profiles in OECD countries). The hump-shape profile could be explained by rising productivity of workers as they gain experience and falling productivity after a certain age.

As shown above, in Sri Lanka relative costs of old vs. young workers appear not to create employment disincentives. The age wage profile for the private sector reaches its peak for the 30-34 age group, slowly decreases thereafter, and experiences a sharp drop after the age of 60. While this drop may reflect the selection process that is not accounted for in age-wage profiles based on cross-section data, the magnitude of the drop of wages of old workers nonetheless 
suggests that the level of wages of old workers - and thus the wage-setting mechanism - is not a disincentive to hire or retain old workers in Sri Lanka.

\section{Other factors}

Work stress and stress of traveling to work may also create obstacles to employment of old workers. As shown above, a fair share of elderly have stopped work due to work stress and the stress of traveling to work. Work stress may be related to many factors, including inappropriate working conditions, discrimination of old workers, or the perception of the old workers about losing their ability to cater the needs of the market. OECD reports that large shares of old workers in OECD countries is exposed to physically unpleasant conditions (43 percent of men and 26 percent of women aged 50-64), and the conditions in Sri Lanka are probably no better.

Another likely obstacle for employment of old workers may be their outdated skills and negative perceptions of employers about the adaptability and productivity of older workers. Even in OECD countries, improving training opportunities and the willingness to take advantage of them have been identified as a key area for strengthening employability of old workers. More research is needed to determine the needs - and the likely impact - of such training in Sri Lanka. And to change negative employer attitudes, a voluntary approach fostering public information campaigns and guidelines about employment of elderly may help.

\section{CONCLUDING REMARKS}

The paper showed that in the coming decades, population aging in Sri Lanka will bring a slowdown of labor force growth and after 2030 its contraction. By studying labor market outcomes of old workers, the paper also demonstrated that labor market duality carries over to old age: while civil servants and formal private sector workers stop working early (generally before they reach 60 years) because they are forced to do so by mandatory retirement provisions, casual workers and the self-employed, in contrast, work until very old age (or death) because they are poor and have to earn their living, and stop working when they are forced to do so for health reasons.

How should labor market and other policies respond to such circumstances? To counter the prospects of labor force reduction, policies could be aimed at increasing participation rates, 
particularly of women and older workers. To increase labor force participation of women, the introduction of family-friendly policies (including increasing part-time working opportunities) would be helpful, as would complementary policies aimed at reducing their burden as primary care givers to old persons (see World Bank 2007b). To increase labor force participation of old workers, retirement age should be made more flexible. More research is needed to examine other possible obstacles for employment of old workers (such as inflexible labor laws) and to determine whether employers' negative perceptions about the adaptability and productivity of older workers create work disincentives for old workers - and if so, what should be done about it.

Another area is improving productivity of the labor force. One important task is to improve skills of older workers through investments in life-long learning. While it is true that older workers undergo training less frequently, increasing the expected duration of their working lives will help them to be more motivated to take training - and it will also increase the payoffs of training to employers. Moreover, OECD (1998) argues that if workers undergo continued training throughout the career, it is unlikely that they would experience a decline in their trainability in the old age. In the context of developing country, the second important route to make labor more productive is formalization of the economy. On this front, one key task is making the labor market legislation less restrictive, so that workers could shift towards better, more productive jobs - and, at the same time, jobs that offer improved social security. And there is also a third channel of raising productivity: improving health outcomes of old workers, the channel that contributes both to higher earning capacity and to longer working careers of workers.

The last point underscores the importance of improving the choices available to old workers. As documented above, many workers - including a vast majority of informal sector workers - stop working only when they are prevented from doing so by ill health, so improving the health status of old people would significantly relieve financial pressures on them. Old peoples' choices would also significantly improve by providing them with an independent source of income, which underscores the need to extend the coverage of old age income support systems. $^{16}$

In a country where extending working lives is key to relieve workers of financial pressures, our finding that ill health - more precisely, according to World Bank 2007b, chronic 
illness - is a major cause of withdrawal from the labor market, deserves special attention. While it highlights the need to formulate a coherent policy for addressing the health challenges of aging, it also points to the special needs of low socioeconomic groups, because these groups, as shown by this study, are most likely to be forced to work long into their old age. Indeed, World Bank (2007b) shows that in Sri Lanka, the burden of ill-health from untreated noncommunicable diseases (NCDs) affects the poor more than the non-poor: the poor have worse access to medical services and so they are less likely than the non-poor to have their NCDs detected and treated. But the need to re-focus health policies to cater better to the needs of old people is clear also from the fact that physical disability rates among the old people in Sri Lanka in the past two decades have increased, in contrast to many other health outcomes. 


\section{References}

Hermalin, A. I. 1995.”Ageing in Asia: Setting the Research Foundation.” Asia-Pacific Research Reports, No. 4. East-West Center, Program on Population.

Hermalin, A. I. 2002. The Well-Being of the Old Persons in Asia: A Four-Country Comparative Study, Ann Arbor: University of Michigan Press.

Hermalin, A. I.; and Yang, L.S. 2004. "Levels of Support from Children in Taiwan: Expectations versus Reality, 1965-99.” Population and Development Review, 30 (3), pp. 417-48.

Institute for Health Policy. 2007. "Socio-Economic and Health Profile of Elderly in Sri Lanka." Background paper prepared for the project on population aging in Sri Lanka, processed, Institute for Health Policy, Colombo.

Kim, I. K. 1999. "Population Ageing in Korea: Social Problems and Solutions.” Journal of Sociology and Social Welfare 26(1): 107-123.

Knodel, J. and M. B. Ofstedal. 2002. “Patterns and Determinants of Living Arrangements.” In A. I. Hermalin (ed). The Well-Being of the Old persons in Asia. University of Michigan Press.

MacKellar F. L. 2000. “The Predicament of Population Aging: A Review Essay,” Population and Development Review, June 2000, v. 26, iss. 2, pp. 365-97.

Martins, J.O., F. Gonand, P. Antolin, C. de la Maisonneuve, and K.Y Yoo. 2005. "The Impact of Aging on Demand, Factor Markets and Growth,” OECD, Economics Working Papers No. 420.

Muenz, R. 2007. "Aging and Demographic Change in European Societies: Main Trends and Alternative Policy Options.” Social Protection Discussion Paper No. 03/07. Washington D.C.: The World Bank.OECD. 2005. Health at Glance: OECD Indicators. Paris, France: OECD.

OECD. 2006. Live Longer, Work Longer. Paris, France: OECD.

de Silva, W. I. 2007. “A Population Projection of Sri Lanka for the New Millenium, 2001-2101: Trends and Implications.” Colombo, Sri Lanka: Institute for Health Policy.

World Bank. 1994. Averting the Old Age Crisis. Policies to Protect the Old and Promote Growth. Washington, DC: The World Bank.

World Bank. 2007a. Sri Lanka: Strengthening Social Protection, World Bank: Human Development Unit, Report No. 38197-LK. 
World Bank. 2007b. Sri Lanka: Addressing the Needs of an Aging Population. World Bank: Human Development Unit, South Asia Region (forthcoming). 
Table 1: Labor force participation by age group from 1992-2004 (\%)

\begin{tabular}{|c|c|c|c|c|c|c|c|c|}
\hline Year & $15-19$ & $20-29$ & 30-39 & $40-49$ & 50-59 & $60-69$ & over 70 & Total \\
\hline 1992 & 32.1 & 89.3 & 96.7 & 95.0 & 80.1 & 54.9 & 21.4 & 75.2 \\
\hline 1993 & 33.8 & 88.7 & 96.9 & 94.6 & 78.5 & 56.0 & 25.6 & 75.6 \\
\hline 1994 & 34.0 & 87.9 & 96.0 & 95.8 & 82.7 & 53.6 & 23.1 & 76.4 \\
\hline 1995 & 31.2 & 87.7 & 96.3 & 94.5 & 82.0 & 51.4 & 22.5 & 74.8 \\
\hline 1996 & 31.0 & 88.6 & 95.8 & 94.7 & 82.5 & 52.5 & 23.8 & 75.4 \\
\hline 1997 & 31.0 & 88.6 & 95.8 & 94.7 & 82.5 & 52.5 & 23.8 & 75.4 \\
\hline 1998 & 35.4 & 89.6 & 97.0 & 95.5 & 84.2 & 56.3 & 23.1 & 77.0 \\
\hline 1999 & 36.7 & 89.1 & 96.7 & 95.0 & 84.9 & 53.5 & 25.7 & 76.7 \\
\hline 2000 & 32.9 & 87.7 & 96.6 & 95.6 & 84.2 & 54.3 & 22.1 & 76.1 \\
\hline 2001 & 28.8 & 88.1 & 96.0 & 95.6 & 84.8 & 52.6 & 21.2 & 75.2 \\
\hline 2002 & 30.1 & 88.5 & 96.9 & 95.3 & 85.4 & 54.8 & 23.6 & 76.7 \\
\hline 2003 & 29.3 & 87.9 & 96.4 & 94.8 & 83.6 & 53.4 & 22.4 & 76.3 \\
\hline 2004 & 29.5 & 88.1 & 96.3 & 94.7 & 83.9 & 51.9 & 18.2 & 76.0 \\
\hline \multicolumn{9}{|c|}{ (b) Females } \\
\hline Year & $15-19$ & $20-29$ & $30-39$ & $40-49$ & $50-59$ & $60-69$ & over 70 & Total \\
\hline 1992 & 21.1 & 52.5 & 45.6 & 40.8 & 25.8 & 11.5 & 3.6 & 36.2 \\
\hline 1993 & 22.8 & 54.2 & 48.7 & 45.9 & 27.1 & 11.4 & 3.4 & 38.2 \\
\hline 1994 & 21.2 & 53.2 & 47.4 & 41.2 & 27.5 & 11.6 & 3.4 & 36.7 \\
\hline 1995 & 19.8 & 51.7 & 46.0 & 44.3 & 28.2 & 14.0 & 3.8 & 36.3 \\
\hline 1996 & 20.1 & 49.9 & 45.4 & 43.6 & 29.6 & 14.5 & 3.2 & 36.1 \\
\hline 1997 & 20.1 & 49.9 & 45.4 & 43.6 & 29.6 & 14.5 & 3.2 & 36.1 \\
\hline 1998 & 23.0 & 54.8 & 51.3 & 50.9 & 34.8 & 17.8 & 5.1 & 40.9 \\
\hline 1999 & 21.3 & 50.6 & 48.7 & 48.0 & 34.5 & 15.4 & 3.4 & 38.2 \\
\hline 2000 & 18.2 & 50.1 & 50.4 & 47.3 & 34.8 & 15.6 & 4.2 & 37.9 \\
\hline 2001 & 17.2 & 49.0 & 44.6 & 45.1 & 34.0 & 15.2 & 3.3 & 35.7 \\
\hline 2002 & 19.0 & 50.0 & 45.4 & 47.2 & 35.6 & 13.5 & 5.0 & 37.4 \\
\hline 2003 & 18.6 & 44.5 & 44.0 & 44.1 & 34.3 & 13.7 & 5.0 & 35.1 \\
\hline 2004 & 18.1 & 45.4 & 43.7 & 44.4 & 33.1 & 14.0 & 3.4 & 35.0 \\
\hline
\end{tabular}


Table 2: Unemployment rate by age group from 1992-2004 (\%)

\begin{tabular}{|c|c|c|c|c|c|c|c|c|}
\hline Year & $15-19$ & $20-29$ & $30-39$ & $40-49$ & $50-59$ & $60-69$ & over 70 & Total \\
\hline 1992 & 38.5 & 20.4 & 4.9 & 2.2 & 1.8 & 1.1 & 0.8 & 10.7 \\
\hline 1993 & 34.5 & 18.2 & 4.9 & 2.3 & 2.3 & 0.2 & 0.2 & 9.6 \\
\hline 1994 & 35.5 & 18.4 & 5.0 & 2.6 & 1.9 & 0.6 & 0.2 & 9.6 \\
\hline 1995 & 31.7 & 18.4 & 4.7 & 2.8 & 0.6 & 0.1 & 0.0 & 9.0 \\
\hline 1996 & 30.1 & 16.9 & 3.5 & 1.0 & 0.7 & 0.7 & 0.0 & 7.6 \\
\hline 1997 & 30.1 & 16.9 & 3.5 & 1.0 & 0.7 & 0.7 & 0.0 & 7.6 \\
\hline 1998 & 25.5 & 13.7 & 2.5 & 1.3 & 0.9 & 0.9 & 0.0 & 6.5 \\
\hline 1999 & 25.5 & 14.3 & 2.5 & 1.5 & 1.6 & 0.5 & 0.4 & 6.8 \\
\hline 2000 & 22.1 & 13.5 & 2.2 & 0.8 & 0.8 & 0.2 & 0.0 & 5.8 \\
\hline 2001 & 28.9 & 14.3 & 1.8 & 1.3 & 0.7 & 0.1 & 0.0 & 6.2 \\
\hline 2002 & 26.9 & 15.7 & 2.2 & 1.4 & 1.0 & 0.3 & 0.0 & 6.6 \\
\hline 2003 & 27.1 & 14.3 & 2.0 & 1.2 & 0.8 & 0.4 & 0.0 & 6.0 \\
\hline 2004 & 26.3 & 14.3 & 2.3 & 1.4 & 0.8 & 1.1 & 0.6 & 6.2 \\
\hline \multicolumn{9}{|c|}{ (b) Females } \\
\hline Year & $15-19$ & $20-29$ & $30-39$ & $40-49$ & $50-59$ & $60-69$ & over 70 & Total \\
\hline 1992 & 46.4 & 39.4 & 12.9 & 4.2 & 0.8 & 1.4 & 0.0 & 22.4 \\
\hline 1993 & 44.9 & 36.6 & 15.1 & 5.3 & 1.9 & 0.0 & 2.1 & 21.7 \\
\hline 1994 & 49.6 & 34.6 & 12.5 & 2.6 & 0.2 & 1.3 & 1.0 & 20.1 \\
\hline 1995 & 48.4 & 33.6 & 12.7 & 2.9 & 0.3 & 0.0 & 0.0 & 18.9 \\
\hline 1996 & 39.6 & 32.0 & 8.3 & 2.8 & 0.7 & 0.4 & 0.0 & 16.2 \\
\hline 1997 & 39.6 & 32.0 & 8.3 & 2.8 & 0.7 & 0.4 & 0.0 & 16.2 \\
\hline 1998 & 30.6 & 28.2 & 9.1 & 3.3 & 0.6 & 0.0 & 0.0 & 14.2 \\
\hline 1999 & 34.1 & 27.0 & 8.0 & 1.7 & 0.9 & 0.2 & 2.2 & 13.2 \\
\hline 2000 & 26.3 & 24.3 & 6.3 & 2.3 & 1.6 & 0.0 & 0.0 & 11.1 \\
\hline 2001 & 31.4 & 25.9 & 6.5 & 1.6 & 0.4 & 0.0 & 1.5 & 11.5 \\
\hline 2002 & 35.4 & 27.2 & 7.2 & 1.7 & 1.1 & 1.2 & 1.9 & 13.0 \\
\hline 2003 & 35.6 & 29.1 & 7.5 & 2.4 & 0.6 & 0.4 & 0.0 & 13.2 \\
\hline 2004 & 37.4 & 29.4 & 6.3 & 2.4 & 0.7 & 0.8 & 0.0 & 13.1 \\
\hline
\end{tabular}


Table 3: International comparisons of labor force participation rates for elderly

\begin{tabular}{|c|c|c|c|c|c|c|c|c|c|c|c|c|c|}
\hline \multirow{2}{*}{$\begin{array}{l}\text { Age grov } \\
\text { Year of da }\end{array}$} & \multicolumn{4}{|c|}{ Sri LanIndia Bangla-dPakistan } & \multicolumn{3}{|c|}{$\begin{array}{l}\text { Thai-lauPhilip.Japan } \\
\text { pines }\end{array}$} & \multicolumn{2}{|c|}{$\begin{array}{l}\text { Hong US } \\
\text { Kong }\end{array}$} & France & Germany & \multicolumn{2}{|c|}{$\begin{array}{c}\text { Norway Switzer- } \\
\text { land }\end{array}$} \\
\hline & 2004 & 2001 & 2003 & 2004 & 2004 & 2004 & 2004 & 2004 & 2004 & 2004 & 2004 & 2004 & 2004 \\
\hline \multicolumn{14}{|l|}{ Males } \\
\hline $50 \neg 54$ & 89.2 & 92 & 99.2 & 94 & 91.6 & & 95.7 & 89.8 & 85.4 & 90.8 & 90.2 & 88.2 & 93.7 \\
\hline 55־59 & 76.4 & & 97.3 & 88.2 & & 88.6 & 93.2 & 75.7 & 77.6 & 67.7 & 80.3 & 81.7 & 89.4 \\
\hline $60 \neg 64$ & 57.7 & 69.7 & 87.8 & 73.1 & 52 & & 70.7 & 43.6 & 57 & 19 & 37.7 & 64.3 & 66 \\
\hline 65ᄀ69 & 43.0 & & 66.1 & 47.5 & & 54 & 45.6 & 9.6 & 32.6 & 4.1 & 7.2 & 26.5 & 22.8 \\
\hline $70-74$ & 25.0 & 49.3 & & & & & 29.3 & & 19.4 & 1.4 & 3.7 & 5.6 & 12.9 \\
\hline Over 75 & 16.8 & & & & & & 14.6 & & 9 & 0.4 & 1.5 & & 6.1 \\
\hline Over 80 & 7.4 & 34.6 & & & & & & & & & & & \\
\hline \multicolumn{14}{|l|}{ Females } \\
\hline $50 \neg 54$ & 37.9 & 40.9 & 19.9 & 18.6 & 70.3 & & 68.4 & 52.1 & 74.5 & 77 & 76.4 & 81 & 78.7 \\
\hline 55־59 & 25.7 & & 17.1 & 14.5 & & 57.3 & 59.6 & 34.8 & 65.0 & 56.2 & 61.7 & 70.9 & 70.1 \\
\hline $60 \neg 64$ & 16.9 & 26.3 & 13.4 & 13.0 & 28.1 & & 39.7 & 12.6 & 45.4 & 16.2 & 19.7 & 52.7 & 38.9 \\
\hline $65 \neg 69$ & 10.1 & & 8.7 & 10.2 & & 30.2 & 24.0 & 1.9 & 23.3 & 2.5 & 4.1 & 19.1 & 10.1 \\
\hline $70-74$ & 5.6 & 13.3 & & & & & 14.9 & & 12.0 & 0.7 & 1.5 & 3.6 & 5.4 \\
\hline $75-80$ & 2.1 & & & & & & 5.8 & & 4.3 & 0.2 & 0.5 & & 2 \\
\hline Over 80 & 1.3 & 8.6 & & & & & & & & & & & \\
\hline
\end{tabular}

Note: Merged cells contain data for the combined age groups. For comparison purposes, labour force participe rates for 65 plus and 75 plus age groups in Sri Lanka are, males - 27.53 and 12.02 and females 5.90 and respectively

Source: ILO, LABORSTA Database 
Table 4: Reasons for complete withdrawal from work of old workers

\begin{tabular}{|c|c|c|c|c|c|c|}
\hline & & $\begin{array}{c}\text { Very } \\
\text { important }\end{array}$ & $\begin{array}{l}\text { Moderately } \\
\text { important }\end{array}$ & $\begin{array}{l}\text { Not important } \\
\text { at all }\end{array}$ & $\begin{array}{l}\text { Don't } \\
\text { know }\end{array}$ & Total \\
\hline & Male & 48 & 17 & 34 & 0 & 100 \\
\hline Health reasons & Female & 47 & 23 & 30 & 0 & 100 \\
\hline \multirow{2}{*}{$\begin{array}{l}\text { To do other things } \\
\text { (hobbies) }\end{array}$} & Male & 8 & 27 & 63 & 2 & 100 \\
\hline & Female & 27 & 31 & 40 & 2 & 100 \\
\hline \multirow{3}{*}{ Family obligations } & Male & 0 & 11 & 84 & 4 & 100 \\
\hline & Female & 3 & 12 & 78 & 7 & 100 \\
\hline & Male & 5 & 8 & 86 & 2 & 100 \\
\hline Disliked work & Female & 9 & 12 & 74 & 4 & 100 \\
\hline \multirow{2}{*}{$\begin{array}{l}\text { Reached mandatory } \\
\text { retirement }\end{array}$} & Male & 37 & 18 & 43 & 2 & 100 \\
\hline & Female & 40 & 16 & 39 & 5 & 100 \\
\hline \multirow{2}{*}{$\begin{array}{l}\text { Traveling to work was } \\
\text { stressful }\end{array}$} & Male & 7 & 17 & 73 & 3 & 100 \\
\hline & Female & 12 & 23 & 60 & 4 & 100 \\
\hline \multirow[b]{2}{*}{ Business closed } & Male & 7 & 5 & 81 & 7 & 100 \\
\hline & Female & 11 & 3 & 74 & 11 & 100 \\
\hline \multirow{2}{*}{$\begin{array}{l}\text { Work was too } \\
\text { stressful }\end{array}$} & Male & 8 & 13 & 77 & 2 & 100 \\
\hline & Female & 11 & 20 & 65 & 4 & 100 \\
\hline
\end{tabular}

Source: Own calculations based on World Bank 2006 Sri Lanka Aging Survey. 
Table 5: Descriptive statistics of variables used in multinomoial logit estimation

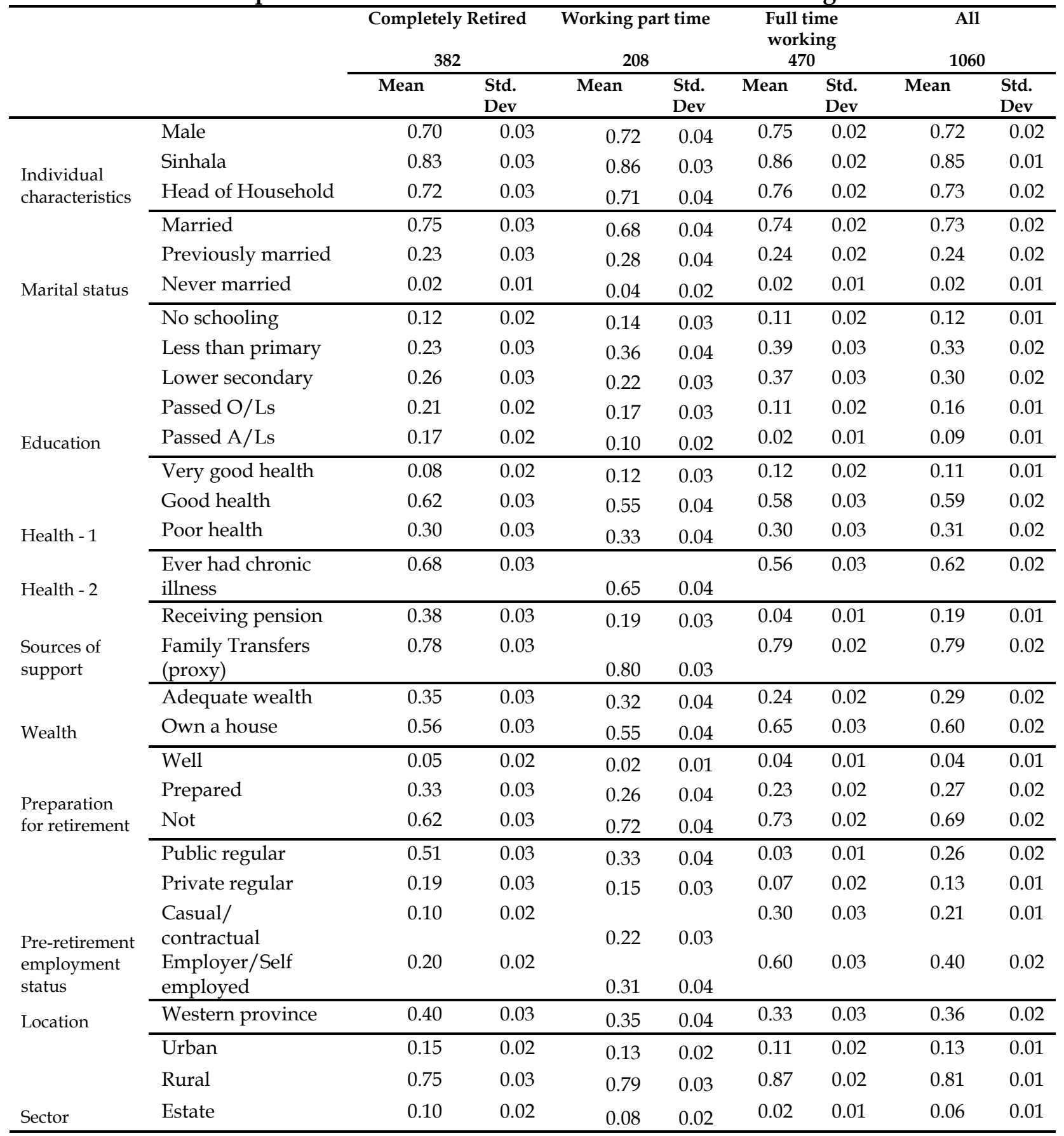

Source: Own calculations using World Bank 2006 Sri Lanka Aging Survey. 


\section{Table 6: Multinomial logit estimates of transition from full-time employment ${ }^{1}$}

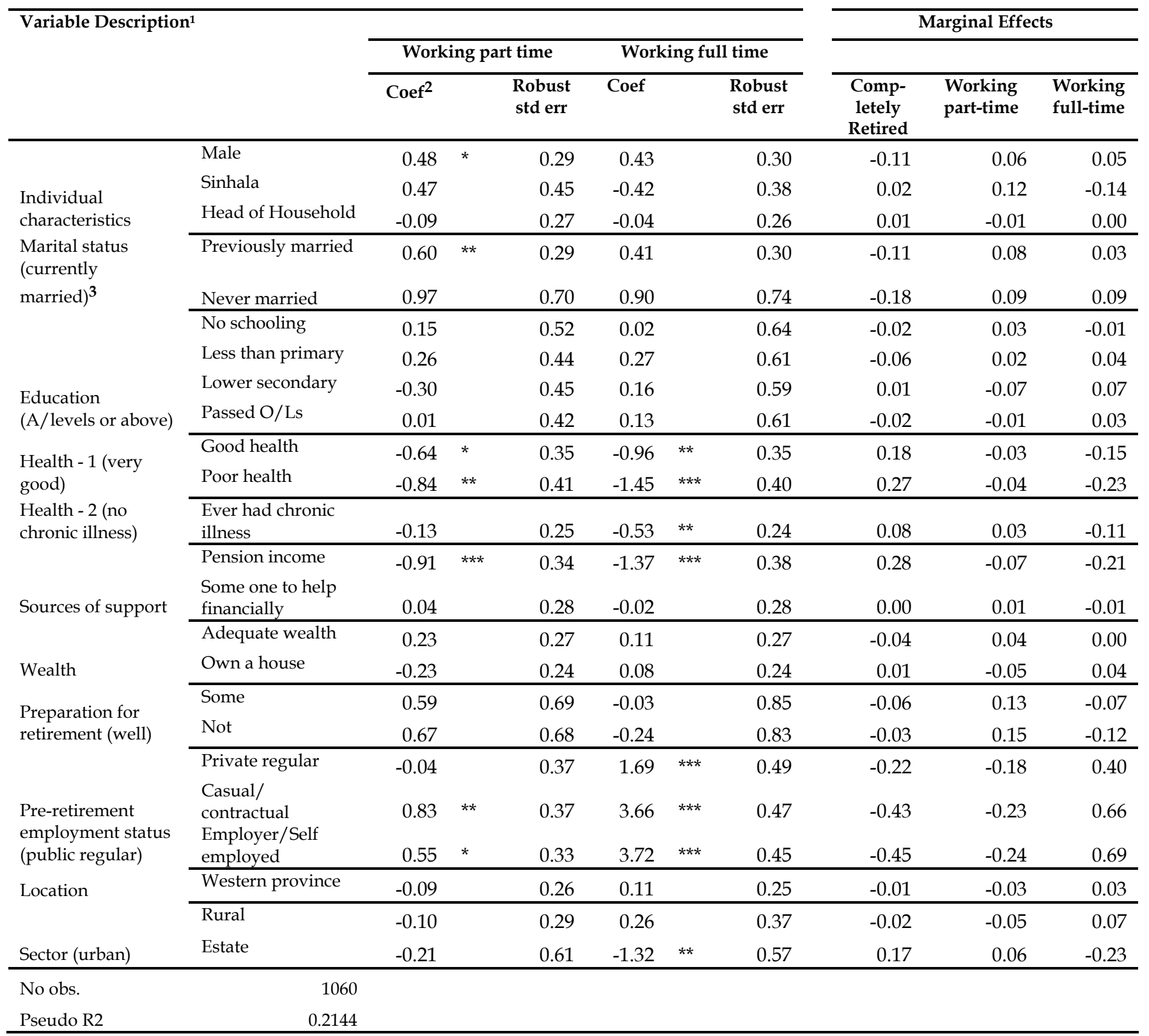

Notes: $\quad 1$. Dependent variable takes three values : completely retiring upon reaching 61 years and not working when aged 61-65 (taken as a baseline); working part time (at least some time during ages 61-65, either part time, or full-time if not throughout the period, and working continuously full-time during ages 61-65.

2. Significance at 1,5 and 10 per cent levels are indicated by '***', '**' and * respectively.

3. Omitted category is given in parenthesis.

Source: $\quad$ Own calculations using World Bank 2006 Sri Lanka Aging Survey 
Figure 1: Demographic aging, Sri Lanka and world regional averages (percentage of population over 60 years old, 2000-2050)

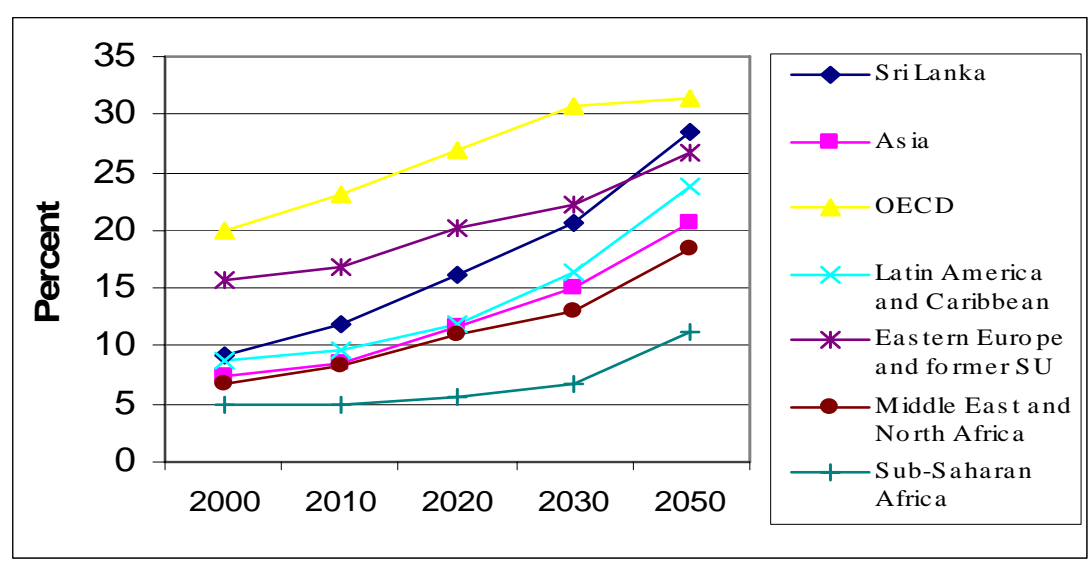

Source: De Silva (2007), for Sri Lanka; World Bank (1994), for other countries 
Figure 2: Trends in dependency ratios, Sri Lanka 2001-2101

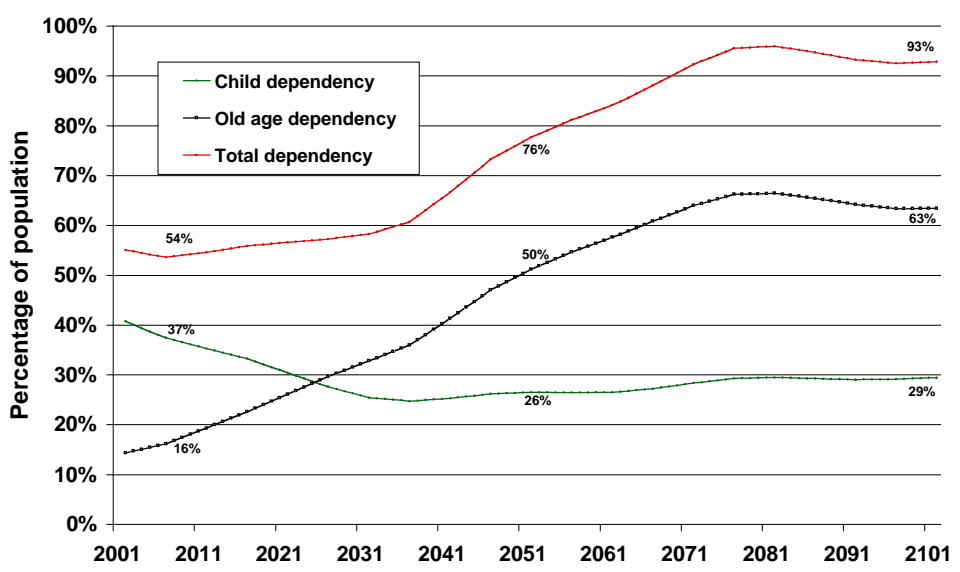

Source: De Silva (2007) 
Figure 3: Labor force projections, 2001-2070

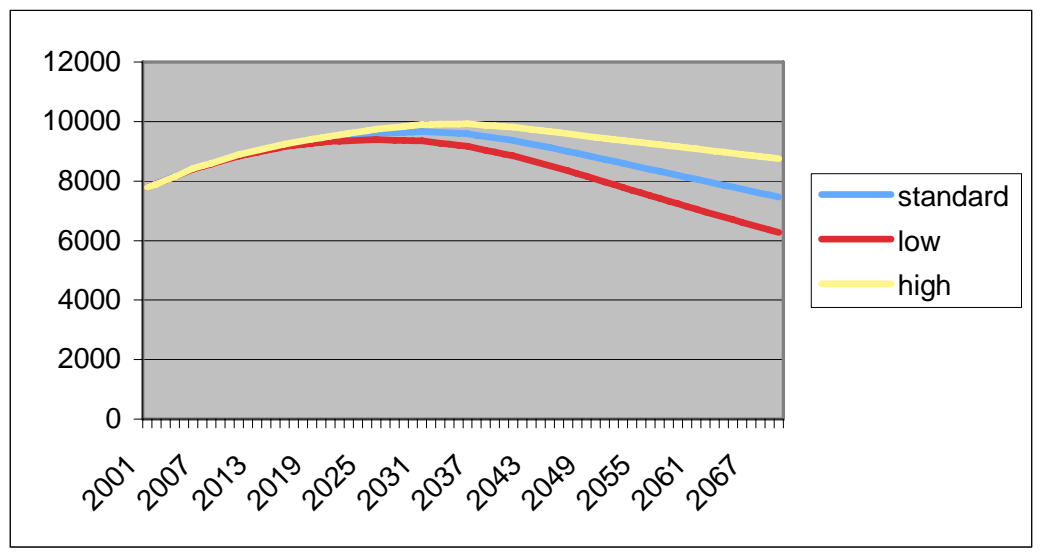

Source: Calculated using population projections by De Silva (2007) and labor force survey data by the Census and Statistics. 
Figure 4: Age composition of standard labor force projections, by gender (2001-2070)
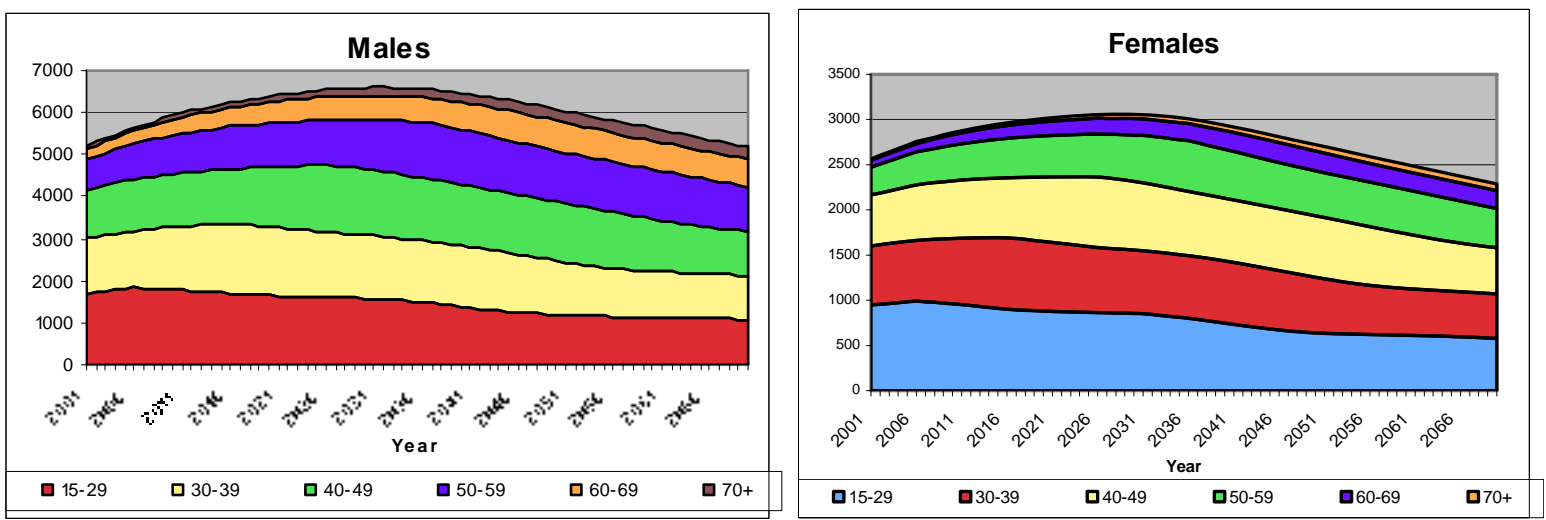

Source: Calculated using population projections by de Silva (2007) and labor force survey data by the Census and Statistics. 


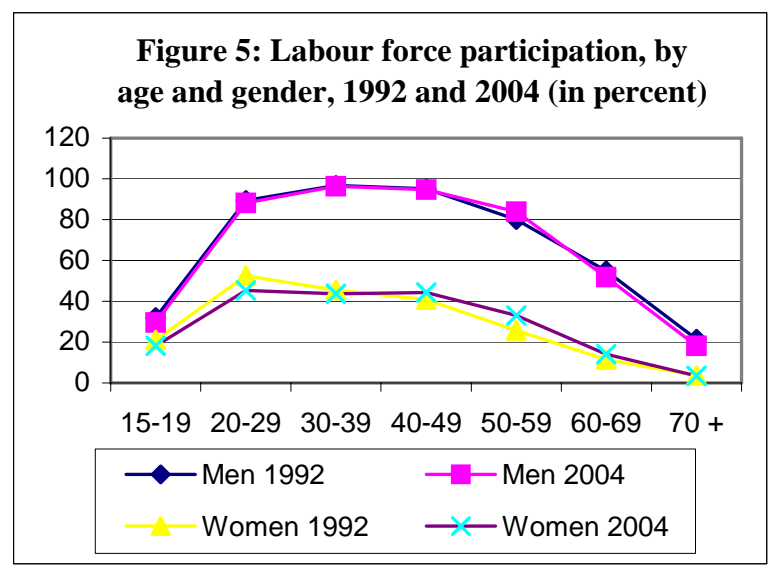

Source: Own calculations based on various Labor Force Surveys of Sri Lanka. 


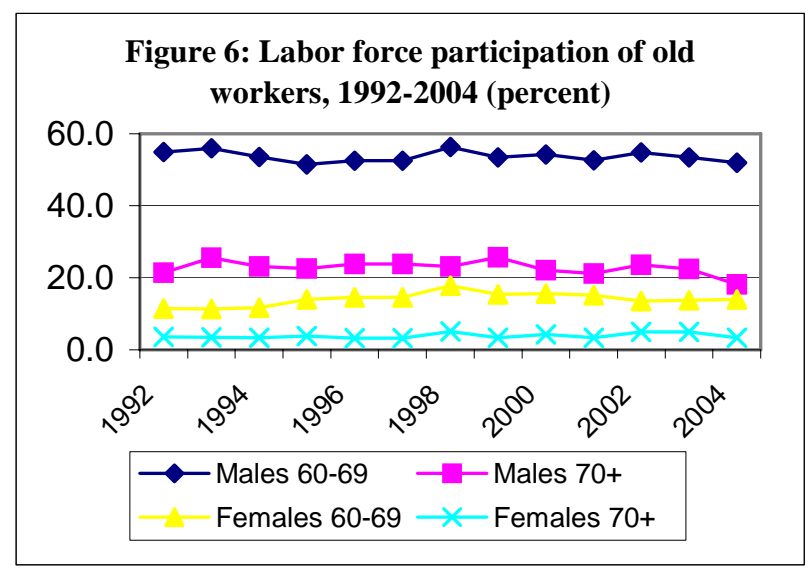

Source: Own calculations based on various Labor Force Surveys of Sri Lanka. 
Figure 7: Unemployment rates by age and gender (1992 and 2004)

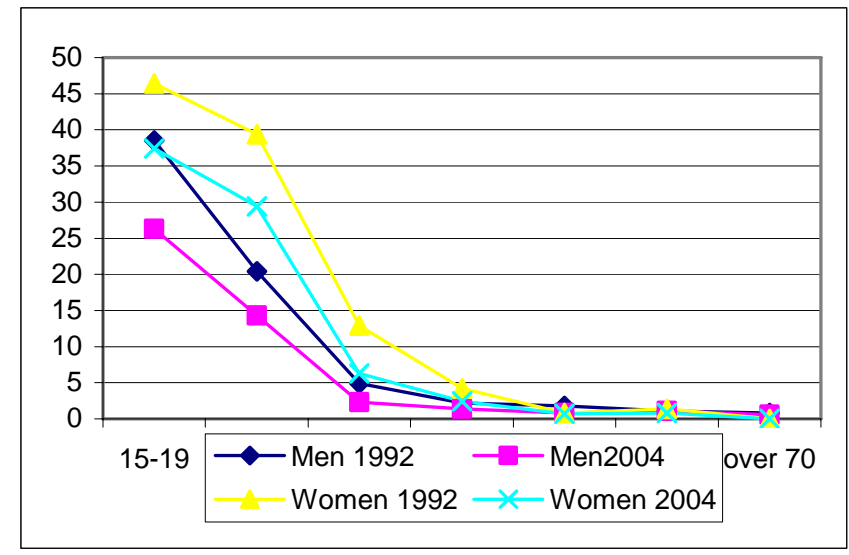

Source: Own calculations based on various Labor Force

Surveys of Sri Lanka. 
Figure 8: Retirement status by age and gender (percent)
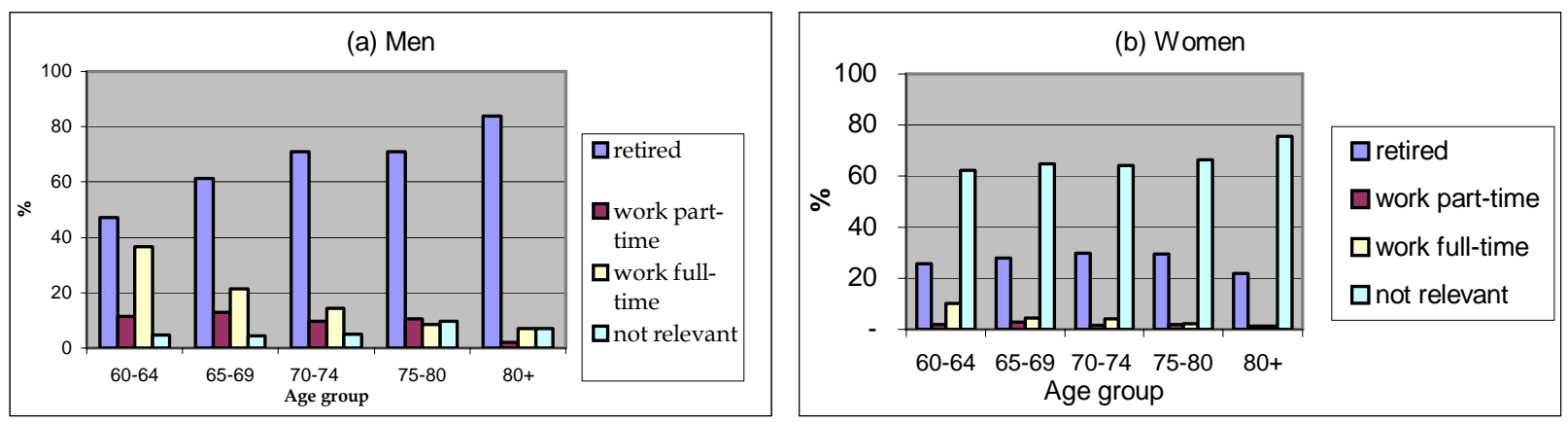

Source: Own calculations based on World Bank 2006 Sri Lanka Aging Survey. 
Figure 9: Average number of hours worked, by age and gender

(a) including fully retired, (b) employed workers only (full- and part-time workers)
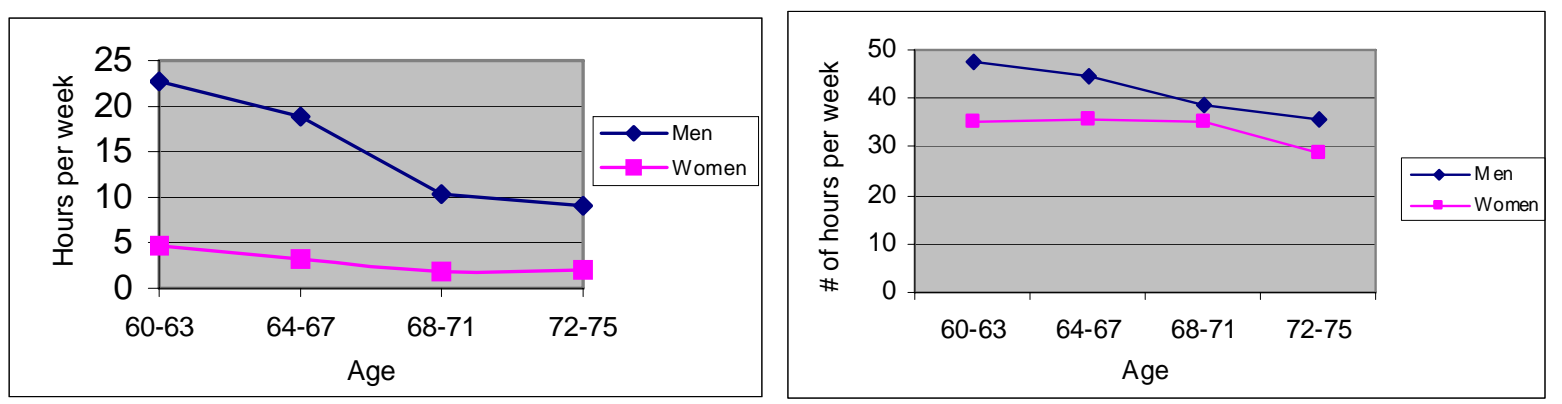

Source: Own calculations based on World Bank 2006 Sri Lanka Aging Survey. 
Figure 10: Age wage profile, by sector and gender

Index (wages for 25-29 year olds $=100$ )

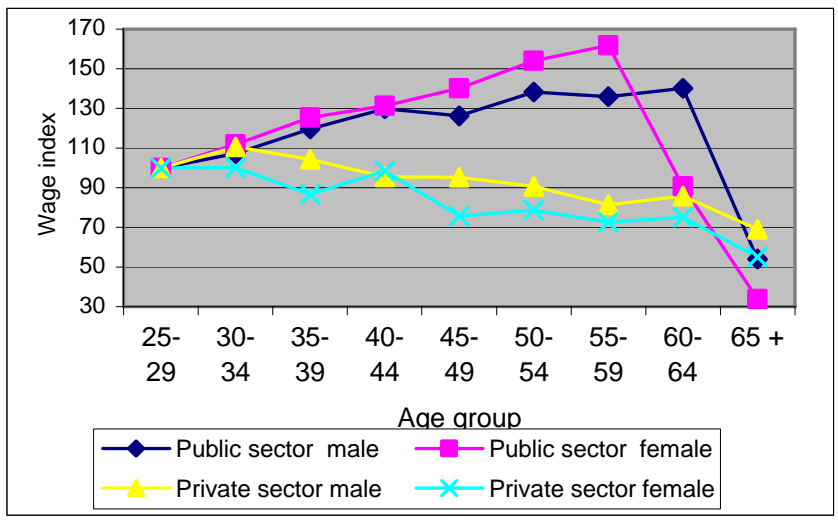

Source: Own calculations based on various Labor Force Surveys of Sri Lanka. 
Figure 11: Old workers by type of employment status and type of employer
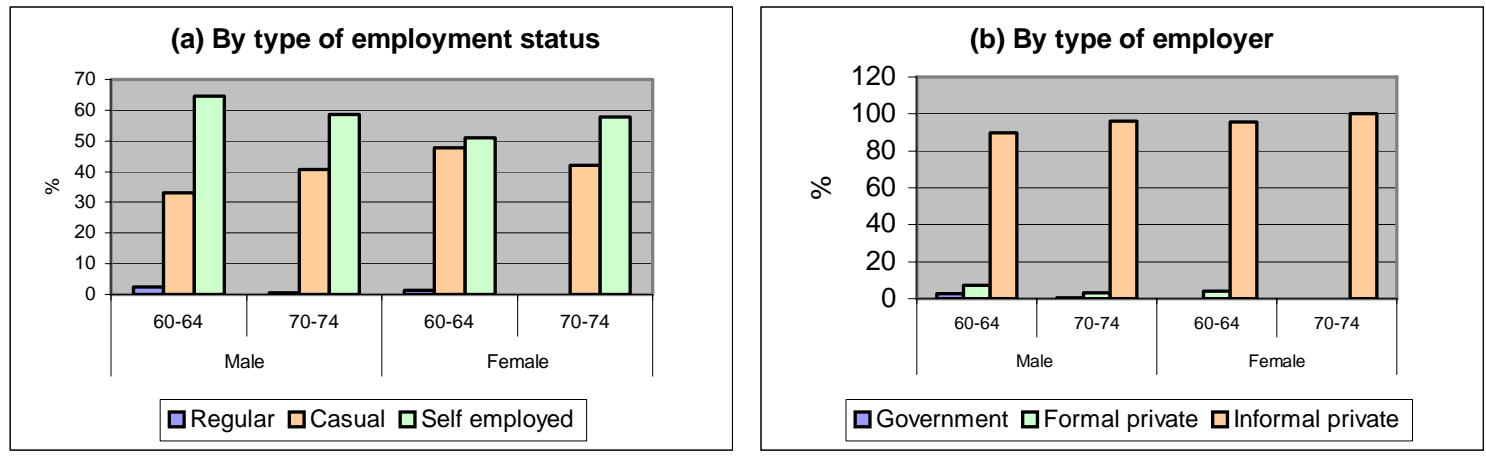

Source: Own calculations based on World Bank 2006 Sri Lanka Aging Survey. 
Figure 12: Old workers by sector of work and occupation
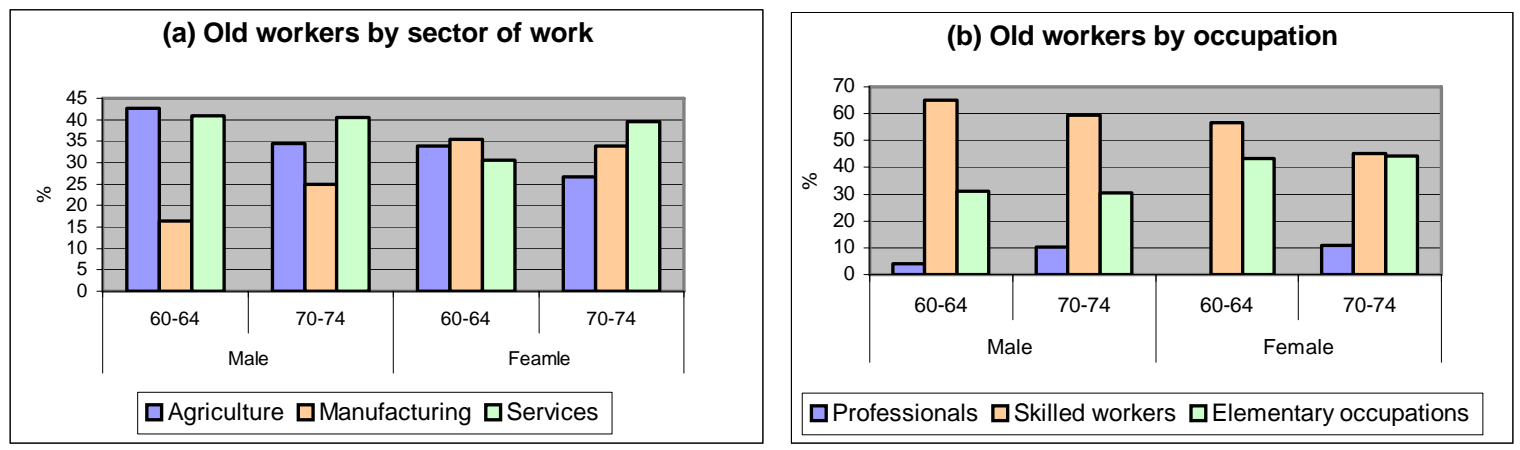

Source: Own calculations based on World Bank 2006 Sri Lanka Aging Survey. 
Figure 13: Retirement status, by prime-age employment type and age
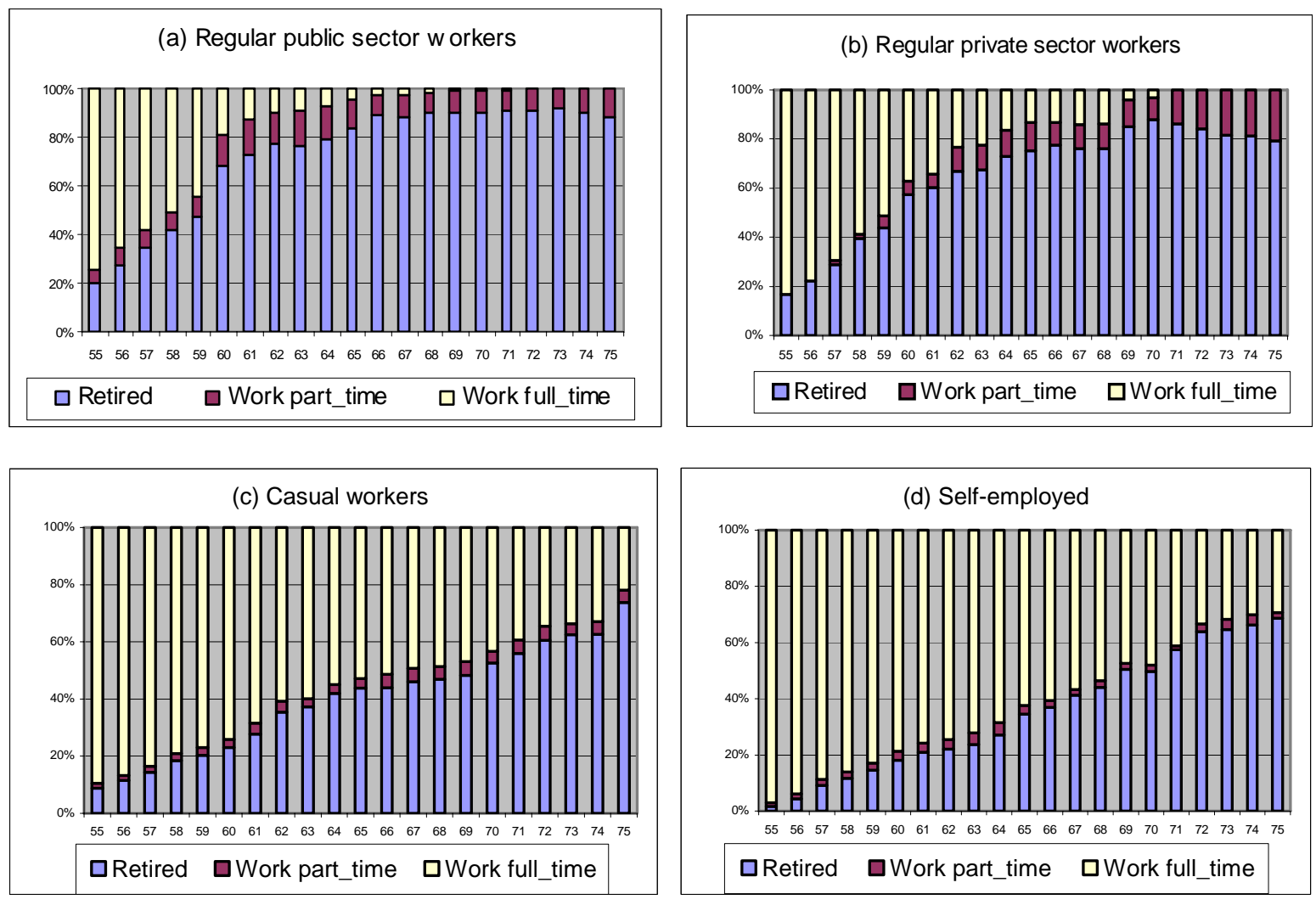

Source: Own calculations based on World Bank 2006 Sri Lanka Aging Survey.

Note: The employment status refers to employment status at age 54. All workers were working full time between ages 51 to 54.

Work related reasons: work stress, travel stress, mandatory retirement, completion of contract, business closed; Health reasons: health reasons or illness, not feeling physically well.

Personal reasons: retirement incentives and family obligations. 
Figure 14: Percentage of retirements by age groups

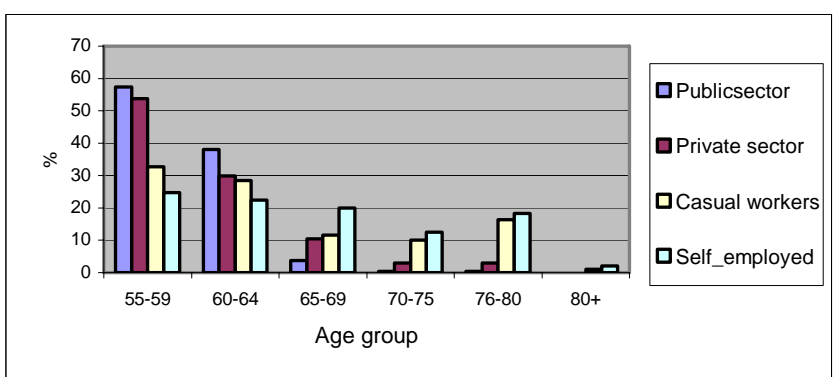

Source: Own calculations based on World Bank 2006 Sri Lanka Aging Survey.

Note: Retirements from full-employment to either complete retirement or part-time work. 
Figure 15: Sector of work, by the prime-age employment type and age
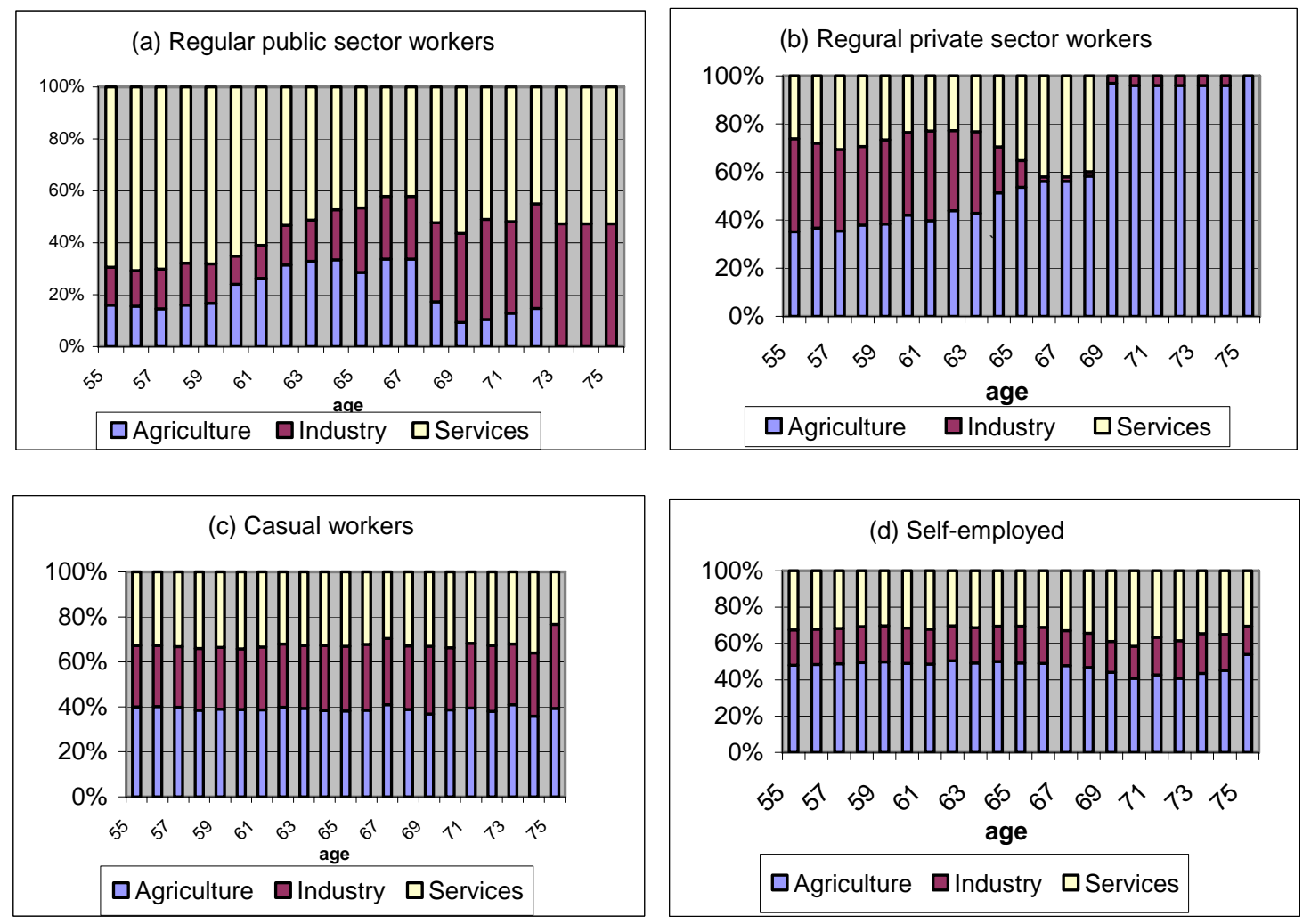

Source: Own calculations based on World Bank 2006 Sri Lanka Aging Survey. 
Figure 16: Reasons for retirement from full time work
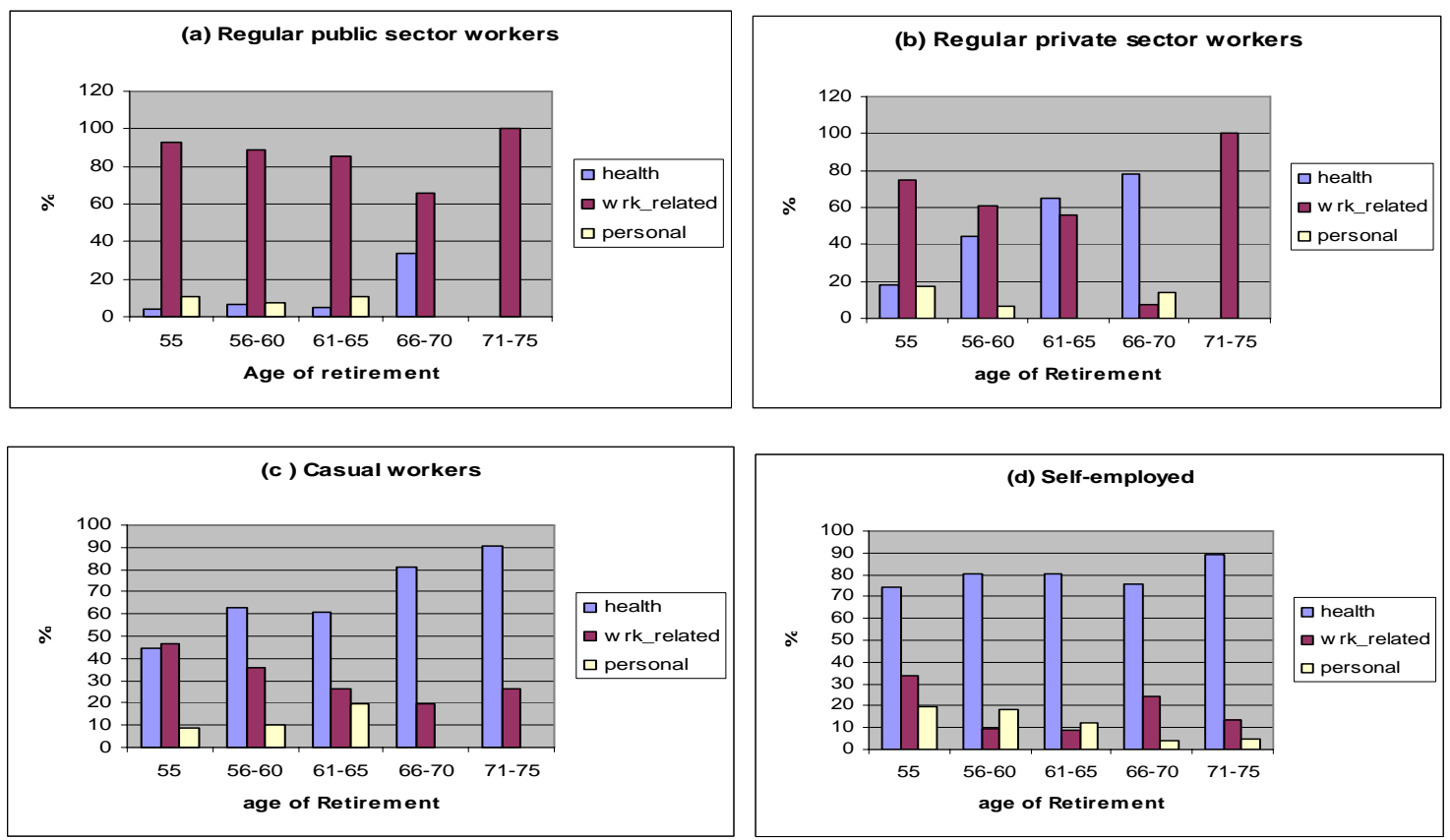

Source: Own calculations based on World Bank 2006 Sri Lanka Aging Survey. 


\section{END NOTES}

${ }^{1}$ While modernization is affecting Asian societies in different ways, there is evidence of declining coresidence of old people with their children in developed Asian countries -- Japan and South Korea (see Hermalin 1995, Knodel and Ofstedal 2002, and Kim 1999), and also of a sharp decline in expected coresidence in Taiwan (Hermalin and Young 2004).

${ }^{2}$ The primary source for this analysis is a 2006 Aging Survey conducted in early 2006 by the World Bank to study the impact of population aging in Sri Lanka. The total number of interviewed persons was 2413, selected randomly among the population of 60 year olds and above. The sample was drawn based on pre-listing of old persons in randomly selected 260 primary sampling units (North-East region was excluded). The questionnaire consisted of several modules, with the present paper using the following ones: background and basic data, activities in which old people have been engaged, income and assets, and health and health care use.

${ }^{3}$ For most developed countries, projections show that their labor forces will stop growing in next decade unless participation rates rise (OECD 2006).

${ }^{4}$ These calculations assume constant future labor force participation rates and apply age and gender-specific labor force participation rates (averages for 2000-04 period) to population projections. We also made projections assuming higher female LFP rates (reflecting possible catching up with developed countries, as currently female participation rates of Sri Lanka lag behind countries such as Japan, Malaysia and Thailand), showing that such increases would delay the shrinking of labor force by a few years.

${ }^{5}$ Simulations for developed countries show that the most powerful countervailing effects can be expected from the increased labor force participation of old workers. Martins et al (2005) show over the long run, the impact of increased retirement age in line with longevity gains prevails over impact of improved labor quality, and that this effect is particularly large for countries currently having low participation rates of older workers. For example, an increased labor force participation scenario in France would turn a decline in labor supply into an increase in labor supply over the next four decades. In Japan, however, the intensity of aging is such that even the combined effect of quality adjustments and increases in participation rates are sufficient to prevent an absolute decline in labor supply by 2050. Similarly, projections for Eastern and Central European countries show that an increased labor force participation of workers aged 40 to 59 years as well those over 60 years old significantly slows down the shrinking of labor force (Muenz 2007).

${ }^{6}$ The explanatory variables used in the regression include age, marital status, education, province, and number of dependent children and old people in the household.

${ }^{7}$ The question on retirement status was not relevant for 66 per cent of elderly females. This arises from the fact that many females do not participate in market based economic activities in younger ages. According to DCS, Labor Force Survey data 60 percent of females 60 to 64 years old are unavailable work, because they are engaged in household activities. Although this percent decreases for elderly age-cohorts even at 80 plus years of age, $6 \%$ of elderly females state that they are not available for work due to household work.

${ }^{8}$ Note that these profiles are derived from cross-section data and may not necessarily reflect life-cycle profiles (that is, age-wage profiles of the same workers traced through time), because these profiles may be heavily influenced by the selection of workers: other things equal, high-paid workers are more likely to withdraw from the labor market later in their career than low-paid workers. The increase of relative wages for workers in their early 60s compared with workers in their late 50s in the private sector thus reflects two opposing effects: the selection effect (that is, a higher likelihood that better paid workers stay employed) as well as the negative effect of age on wages of life-cycle wage profile, with the former prevailing (that is, better-paid workers self-select and continue working while lowerpaid workers transfer to inactivity).

${ }_{9}^{9}$ As described, for example, by OECD (2006), pull factors are associated primarily with financial incentives provided by pension schemes and family obligations such as helping with childcare of grand children, and push factors with firm and personal circumstances that restrict job opportunities of old workers (such as perceptions about the capacities of old workers and mandated benefits or increases in wages associated with age or work experience).

${ }^{10}$ Unpaid family workers were not included in the analysis, due to small (20 observations) sample size.

${ }^{11}$ According to the pre-retirement employment status, the total sample of 1060 individuals is divided into 276 regular public sector workers, 138 regular private sector workers, 223 casual workers, and 424 self-employed (the data are right censored).

${ }^{12}$ A log rank test showed that the survival curves for the four sectors of employment - that is, regular public sector workers, regular private sector workers, casual workers and self employed - were statistically different. 
${ }^{13}$ Sri Lanka's severance pay system - embodied in the Termination of Employment of Workman Act (TEWA) of 1971 - is one of the costliest and most restrictive severance pay systems in the world. The TEWA requires employers with more than 14 workers to seek the authorization of the Commissioner of Labor for intended layoffs. It not only requires that employers pay high compensation to laid off workers, but its discretionary nature and lengthy procedures further restrict the ability of employers to lay off workers. By ex-ante determining the amount of severance pay, the recently introduced formulas somewhat reduced arbitrariness, but payments remain well above international norms (for a description and consequences of TEWA, including on firms' growth and job dynamics, see World Bank 2007a).

${ }^{14}$ For example, OECD (2006) reports that firms in Japan and Korea are massively resorting to mandatory retirement age in order to evade strict employment protection legislation, because this legislation does not apply to mandatory retirements.

${ }^{15}$ Based on cross-country analysis, OECD (2006) provides some evidence of a negative impact of high relative wages on employment opportunities of old workers (drop in retention and hiring rates of male older workers).

${ }^{16}$ World Bank (2007b) points to the weaknesses of the current schemes for informal workers in Sri Lanka and lays out an alternative strategy to expanding social security to informal sector workers. 